Journal of Materials and Environmental Sciences ISSN : 2028-2508

CODEN : JMESCN

Copyright $\odot 2017$

University of Mohammed Premier

Oujda Morocco

\title{
Chemical Investigation and Antimicrobial Activity of Francoeuria crispa (Forssk) Grown Wild In Egypt
}

\author{
S. S. Ahmed, M. E. Ibrahim \\ Research of Medicinal and Aromatic Plants Department, National Research Center, Dokki, 12622, Cairo, Egypt
}

Received 27 Feb 2017,
Revised 30 Mar 2017,
Accepted 02 Apr 2017

Keywords
$\checkmark \quad$ Francoeuria
$\quad$ crispa (Forssk);
$\checkmark$ phytochemical
$\quad$ screening;
$\checkmark$ antimicrobial;
$\checkmark$ Essential oils;
$\checkmark$ constituents;
$\checkmark$ piperitone

S. S. Ahmed
mokatabat513@yahoo.com

\begin{abstract}
Survey and evaluation of wild plants that grow in Egyptian desert are of the priorities of the current study, so this present survey was carried out to examine the composition and antimicrobial activity of Francoeuria crispa (Forssk) plant growing wild in eastern Egyptian desert. Francoeuria crispa is an annual herb or sometimes a perennial subshrub producing small bright yellow flowers. The plant materials were collected from the plants growing on eastern desert approximately $1200 \mathrm{~km}$ out of Cairo. The chemical composition of the volatile oil, isolated by hydrodistillation of the herb, was investigated by GC and GC-MS. The percentage of essential oil of $F$. crispa (Forssk.), obtained in $0.23 \%$ v/w on a dry weight basis, consisted approximately of piperitone $45.0 \%$. Other oxygenated monoterpene compounds were found; the principal members were, cis-sabinene hydrate, $(0.35 \%)$ linalool $(0.85 \%) \alpha$-terpineol $(1.08 \%)$, neral $(0.80 \%))$, linalyl acetate $(0.47 \%)$ and, anethole trans $(1.0 \%)$. Oxygenated monoterpene (OMG) group gave the highest percentage (50.85\%) against $6.69,4.8$ and $27.77 \%$ for monoterpene hydrocarbon group (MHG), sesquterpenes hydrocarbon group (SHG) and oxygenated sesquterpenes group (OSG) respectively. The results proved that, F. crispa is rich in carbohydrates or glycoside, sterols and flavonoids. Tannins and coumarins are found in moderate amounts, while, alkaloids, saponins and anthraquinones are absent. The antimicrobial activities of the water and alcohol extracts of $F$. crispa herb were carried out using the inverted Petri plate method. The water and alcohol extraction showed prominent antimicrobial activities against fungi, gram positive and gram negative bacteria at a very low concentration $(10 \mu \mathrm{l})$.
\end{abstract}

\section{Introduction}

Francoeuria crispa (Forssk) syn. Pulicaria crispa (Forssk.), Pulicaria undulata (1.) (family Asteraceae) is an annual herb or sometimes a perennial subshrub producing small bright yellow flowers. This species is distributed in Egypt, Saudi Arabia, Kuwait, Iraq, Iran, Pakistan, India, Afghanistan and parts of North and West Africa [1-2]. Francoeuria crispa is an aromatic herb used in folk medicine in Egypt and Saudi Arabia for the treatment of inflammation. It is also repellent to insects [3] and it used as an herbal tea [4]. The constituents of $P$. undulata (L.) from Saudi Arabia was investigated by GC/MS. The P. undulata (L.) oil is rich in phenolic compounds and monoterpene hydrocarbons (MHG) with low incidence of sesquterpenes hydrocarbons (SHG) [5]. The oil of $P$. undulata aerial parts exhibited inhibitory activity against Gram-positive and Gram-negative bacteria [6]. Undoubtedly, there is a clear and great interest in the moment of medicinal and aromatic plants as an important source of raw materials for the pharmaceutical treatment of many diseases and as an alternative to the use of chemicals. This is mainly due to the strong biological activity, where it is considered as safe, economical and powerful natural antioxidant [7]. Many investigators reported that, secondary metabolites are known to have many the therapeutic activities against many diseases in human categories; therefore, traditional medicinal plants can be used for treating many diseases [8-14] This present work was carried out to study the essential oil content, phytochemical screening and antimicrobial activities of $F$. crispa wild grown under Egyptian conditions.

\section{Materials and methods}

\subsection{Plant material}

The areal parts were collected from wild plant populations of Francoeuria crispa (Forssk) growing in sandy soils on Gebel Elba region approximately $1200 \mathrm{~km}$ south of Cairo in March 2013 (During flowering stage). Identification of the species was achieved by Prof. Dr. Loutfy Boulos [15-16]. Voucher specimens are in the herbarium of NRC, Cairo, Egypt. 


\subsection{Essential oil isolation}

Five hundred grams from dried herb were subjected to hydro-distillation for 3 hrs using a Clevenger-type apparatus [17]. The essential oil content was calculated as a relative percentage (v/w). The samples of the essential oils were dehydrated over anhydrous sodium sulfate and stored in refrigerator until analyzed.

\subsection{Gas chromatography $(G C)$}

GC analyses were performed using a Shimadzu GC- 9A gas chromatograph equipped with a DB5 fused silica column $(30 \mathrm{~m} \times 0.25 \mathrm{~mm}$ i.d., film thickness $0.25 \mu \mathrm{m})$. Oven temperature was held at $40^{\circ} \mathrm{C}$ for $5 \mathrm{~min}$ and then programmed until $250^{\circ} \mathrm{C}$ at a rate of $4^{\circ} \mathrm{C} / \mathrm{min}$. Injector and detector (FID) temperature were $260^{\circ} \mathrm{C}$; helium was used as carrier gas with a linear velocity of $32 \mathrm{~cm} / \mathrm{s}$.

\subsection{Gas chromatography-Mass spectrometry (GC-MS)}

GC-MS analyses were carried out on a Varian 3400 system equipped with a DB-5 fused silica column (30 m x $0.25 \mathrm{~mm}$ i.d.); Oven temperature was 40 to $240^{\circ} \mathrm{C}$ at a rate of $4^{\circ} \mathrm{C} / \mathrm{min}$, transfer line temperature $260^{\circ} \mathrm{C}$, injector temperature $250^{\circ} \mathrm{C}$, carrier gas helium with a linear velocity of $31.5 \mathrm{~cm} / \mathrm{s}$, split ratio $1 / 60$, flow rate $1.1 \mathrm{ml} / \mathrm{min}$, Ionization energy $70 \mathrm{eV}$; scan time 1 mass range 40-350 amu.

\subsection{Qualitative and quantitative analyses of essential oil}

Identifications were made by library searches (Adams, 1995) [18] combining MS and retention data of authentic compounds by comparison of their GC retention indices (RI) with those of the literature or with those of standards available in our laboratories. The retention indices were determined in relation to a homologous series of n-alkanes (C8-C22) [19] under the same operating conditions. Further identification was made by comparison of their mass spectra on both columns with those stored in NIST 98 and Wiley5 Libraries or with mass spectra from literature. Component relative concentrations were calculated based on GC peak areas without using correction factors.

\subsection{Preparation of the crude extracts}

\subsubsection{Alcoholic extract}

The 80\% ethanolic extracts are prepared following the process described [20]; $100 \mathrm{~g}$ of the aerial parts of each plant were collected, dried in the oven at $40{ }^{\circ} \mathrm{C}$ and reduced to powder. They were separately macerated with the $80 \%$ ethanol and allowed to stand for $72 \mathrm{hrs}$ and then filtered. The filtrates were then evaporated under reduced pressure and dried using a rotary evaporator at $50^{\circ} \mathrm{C}$. Dried extracts were stored in labeled sterile screw capped bottles at $5^{\circ} \mathrm{C}$ in the refrigerator, until when required for use.

\subsubsection{Water extract}

One hundred gm of the dried powder of each plant were macerated in water at room temperature for $24 \mathrm{hrs}$. The macerates were filtered and evaporated under vacuum till dryness. The residues were kept for testing and antimicrobial activity

\subsection{Phytochemical screening:}

The powdered air-dried aerial parts of plant under study was screened for carbohydrates and / or glycosides; sterols and / or triterpenes, flavonoids, tannins, saponins, coumarins and alkaloids, applying chemical tests [21]

\subsection{Biological Activity:}

\subsubsection{Plant extraction}

The dry aerial parts of the tested herb were extracted by $80 \%$ alcohol. The extract was evaporated under vacuum and the residue was dissolved in alcohol to give concentration of $100 \mu \mathrm{g} / \mathrm{ml}$.

\subsubsection{Microbiological techniques}

Microbial strains: The antimicrobial activity of alcoholic and water extracts were tested against some bacterial strains (Gram negative bacteria (G-): Escherichia coli, Proteus vulgaris, Salmonella typhi. (Gram positive bacteria (G+): Bacillus subtilis, Pseudomonas fluroscens, Lactobacillus breveis, Staphylococcus aureus and chromobacter sp), one fungal strain (Aspergillus niger) and one yeast strain (Candida albicans). Tested organisms were obtained from the Faculty of Agriculture, Cairo University.

\subsection{Agar diffusion method}

This method agar diffusion assay was carried out [22]. Nutrient agar was used for the cultivation of bacteria and yeast; while Czapek-Dox's medium (Dox 1910) was used for cultivation of fungal species. In this method, presterilized Whatman no.1 filter paper discs $(5 \mathrm{~mm}$ in diameter) (Whatman International Ltd., Maidstone, England) were impregnated with $100 \mu \mathrm{l}$ of the extract $(100 \mu \mathrm{g} / \mathrm{ml})$ and was allowed to dry (to get rid of the 
alcohol) and was then applied on the surface of agar plates freshly seeded with standard inoculate of young cultures, 24-hrs-old bacteria and yeast, and 7-days-old fungi. The plates of test organisms were then incubated at $27^{\circ} \mathrm{C}$ for $24 \mathrm{hrs}$ for bacteria \& yeast and for $48 \mathrm{hrs}$ for fungi. At the end of the incubation period, the inhibition zones were measured (results are the average of triplicate measurements).

\subsection{Statistical analysis of data}

All values of the antimicrobial activity were expressed as the mean of inhibition zones $(\mathrm{mm})$ with three replicates for each treatment. Data were subjected to a paired-sample $t$-test using SPSS (ver. 9.0). $P<0.05$ was regarded as significant.

\section{Results and discussion}

\subsection{Preliminary phytochemical screening}

Data presented in Table (1) show the preliminary phytochemical screening of the dried aerial parts of $F$. crispa in the flowering stage. Phytochemical examination of the alcoholic extracts showed that. F. crispa is rich in volatile oils (natural compounds, characterized by, a strong aromatic odor), carbohydrates (energy source of living creatures), Sterols and/or terpenes (natural fatty substances) and flavonoids (antioxidant and antiinflammatory substances). In addition, the dried aerial parts of $F$. crispa contain low amounts of tannins and coumarins. At the same time data in Table 1 confirm the absence of alkaloids, saponins and anthraquinones.

Table 1. Results of preliminary phytochemical screening of Francoeuria crispa

\begin{tabular}{|l|l|}
\hline Chemical group & Phytochemical screening \\
\hline Volatile oils & high value (++) \\
\hline $\begin{array}{l}\text { Carbohydrates and / or } \\
\text { glycosides }\end{array}$ & high value (++) \\
\hline Sterols and or terpenes & high value(++) \\
\hline Flavonoids & high value(++) \\
\hline Tannins & Low Value (+) \\
\hline Alkaloids & Absent (-) \\
\hline Saponins & Absent (-) \\
\hline Coumarins & Low value (+) \\
\hline Anthraquinones & Absent(-) \\
\hline
\end{tabular}

\section{3-2 Essential oil constituents of F. crispa (Fig. 1)}

The essential oil extracted by water distillation from aerial parts of $F$. crispa yielded $0.23 \%(\mathrm{v} / \mathrm{w}$ ) based on a dry weight. Twenty-three compounds representing $90.11 \%$ of the Egyptian $F$. crispa essential oil were identified (Table 2). The main constituents of Egyptian F. crispa oil are piperitone (45.0\%), elemol (8.59\%), $\beta$-eudesmol $(8.17 \%), \alpha$-eudesmol (5.35\%), cis- nerolidol (4.5\%), $\alpha$-terpinene $(3.89 \%)$.

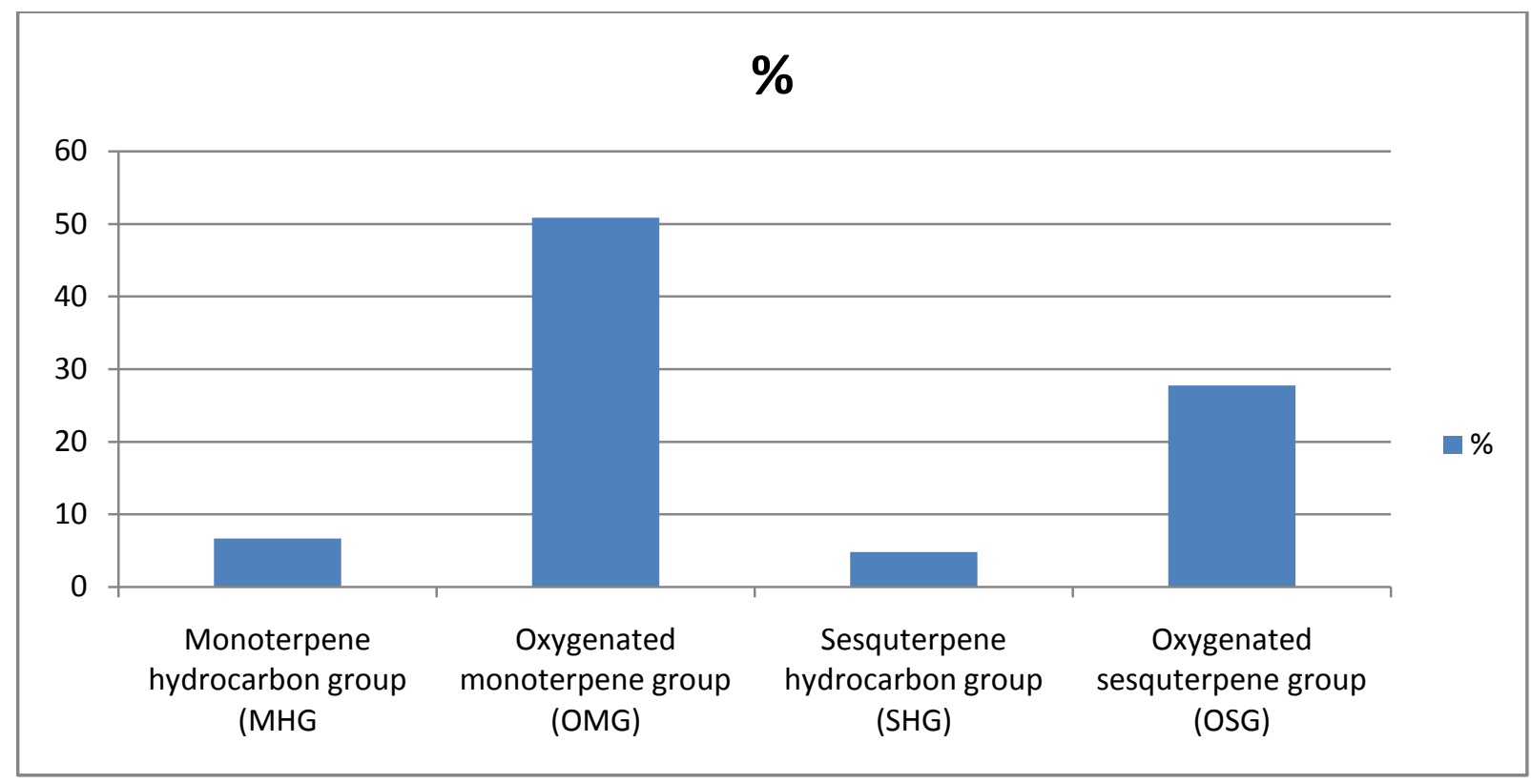

Fig 1 : Percentage of different chemical groups in Francoeuria crispa oil. 
Essential oil of $F$. crispa from Egypt grouped into four groups which are monoterpene hydrocarbons group (MHG), oxygenated monoterpene group (OMG), sesquterpenes hydrocarbons group (SHG) and oxygenated sesquterpenes group (OSG). The data in the same Table indicated that the (OMG) gave the highest concentrations (50.85\%), followed by (OSG) (27.77\%), (MHG) $(0.69 \%)$ and (SHG) (4.8\%). (OMG) included cis-sabinene hydrate, linalool, $\alpha$-terpineol, neral, geranal, piperitone, linalyl acetate and trans-anethole. $\alpha$ terpinene $(3.89 \%)$ is the major constituent of the (MHG) of F. crispa essential oil.

Table 2. Chemical constituents of essential oil extracted from Francoeuria crispa plant

\begin{tabular}{|c|c|c|c|}
\hline Peak No & Compound & $K I$ & $\%$ \\
\hline \multicolumn{4}{|c|}{ Monoterpene hydrocarbon group (MHG) } \\
\hline 1 & $\alpha-$ Pinene & 939 & 0.23 \\
\hline 2 & Sabinene & 976 & 0.17 \\
\hline 3 & 2-Carene & 1001 & 1.33 \\
\hline 4 & $\alpha$-Terpinene & 1018 & 3.89 \\
\hline 5 & Limonene & 1039 & 0.31 \\
\hline 6 & $\gamma$-Terpinene & 1062 & 0.53 \\
\hline 7 & 2,5 Dimethylstyrene & 1096 & 0.23 \\
\hline Total (MHG) & & & 6.69 \\
\hline \multicolumn{4}{|c|}{ Oxygenated monoterpene group $(O M G)$} \\
\hline 1 & cis-Sabinene hydrate & 1097 & 0.35 \\
\hline 2 & Linalool & 1098 & 0.85 \\
\hline 3 & a-Terpineol & 1189 & 1.08 \\
\hline 4 & Neral & 1240 & 0.80 \\
\hline 5 & Geranal & 1241 & 1.30 \\
\hline 6 & Piperitone & 1252 & 45.0 \\
\hline 7 & Linalyl acetate & 1257 & 0.473 \\
\hline 8 & trans-Anethole & 1283 & 1.00 \\
\hline Total (OMG) & & & 50.85 \\
\hline \multicolumn{4}{|c|}{ Sesquterpene hydrocarbon group (SHG) } \\
\hline 1 & $\beta$-Caryophyllene & 1418 & 0.75 \\
\hline 2 & $\beta-$ Gurjunene & 1432 & 2.95 \\
\hline 3 & $\gamma$-Muurolene & 1477 & 1.10 \\
\hline Total (SHG) & & & 4.80 \\
\hline \multicolumn{4}{|c|}{ Oxygenated sesquterpene group (OSG) } \\
\hline 1 & cis Nerolidole & 1525 & 4.50 \\
\hline 2 & Elemol & 1549 & 8.59 \\
\hline 3 & Caryophyllene oxide & 1581 & 1.16 \\
\hline 4 & $\alpha$-Eudesmol & 1652 & 5.35 \\
\hline 5 & $\beta-$ Eudesmol & 1652 & 8.17 \\
\hline Total(SOG) & & & 27.77 \\
\hline Total contents & & & 90.11 \\
\hline
\end{tabular}

Other minor compounds in this group were detected as, $\alpha$-pinene, sabinene, 2 -carene, limonene, $\gamma$-terpinene and 2,5-dimethyl styrene. The main constituents of (SHG) were cis- nerolidol, elemol, caryophyllene oxide, $\alpha$ eudesmol and $\beta$ - eudesmol. These compounds amounted to 4.5, 8.59, 1.16, 5.35 and 8.17\%, respectively. From the above data, it was observed that there are significant differences in the composition of $F$. crispa essential oil produced under Egyptian conditions in comparison with the oil produced under the other conditions [23], especially the contents of the major components. In Egypt the main constants of $F$. crispa were piperitone elemol and eudesmol, while, under the Iran conditions, the three major constituents were 4-terpineole (20.12\%), $\gamma$-terpinene $(7.0 \%)$ and $\alpha$-terpinene $(4.02 \%)$. These results are consistent with the Szeveni-Galambosi et. al. (1992) [24] who proposed some chemo-types of some aromatic plants based on the dissimilar biosynthetic pathways which reflected the chemical contents of the essential oils formed under different conditions (different regions). Therefore, terpenoids as natural products differs constituently by regions with different conditions. 


\section{Antimicrobial activities}

The Antimicrobial activity was tested using gram negative bacteria: Escherichia coli, Proteus vulgaris, and Pseudomonas fluroscens Salmonella typhi, gram positive bacteria: Bacillus subtilis, Chromobacter sp, Lactobacillus breveis, Staphylococcus aureus, yeast: Candida albicans and fungi Aspergillus niger. Data in Table 3 recorded that, the investigated water plant extract was effective against $E$. coli (inhibition zone 12.00 $\mathrm{mm}$ in diameter) against $(15.00 \mathrm{~mm})$ for $80 \%$ alcoholic extract.

Table3. Antimicrobial assay of F. crispa growing wild plant in eastern Egyptian desert.

\begin{tabular}{|c|c|c|c|}
\hline Strains & Water extract & $80 \%$ alcoholic extract & Standard $100 \mu \mathrm{g} / \mathrm{disk}$ \\
\hline Gram-negative bacteria (G-) & \multicolumn{2}{|c|}{ Inhibition zone ( $\mathrm{mm}$ in diameter) $\pm \mathrm{SE}$} & \\
\hline Escherichia coli & $12.00 \pm 0.65$ & $15 \pm 1.13$ & $16.0 \pm 0.6$ \\
\hline Proteus vulgaris & 0 & 0 & $21 \pm 0.90$ \\
\hline Pseudomonas fluroscens & 0 & 0 & $26 \pm 0.39$ \\
\hline Salmonella typhi & 0 & 0 & $19 \pm 0.83$ \\
\hline \multicolumn{4}{|l|}{ Gram -positive bacteria $(\mathrm{G}+)$} \\
\hline Bacillus subtilis & $12.00 \pm 0.5$ & $14.00 \pm 1.20$ & $24 \pm 0.51$ \\
\hline Chromobacter $s p$ & 0 & + & NT \\
\hline Lactobacillus breveis & 0 & $7.00 \pm 0.33$ & NT \\
\hline Staphylococcus aureus & 0 & 0 & $22 \pm 0.80$ \\
\hline \multicolumn{4}{|l|}{ Yeast } \\
\hline Candida albicans & 0 & 0 & $12 \pm 0.53$ \\
\hline \multicolumn{4}{|l|}{ Fungi } \\
\hline Aspergillus niger & $12 \pm 43$ & 0 & $9.0 \pm 0.01$ \\
\hline
\end{tabular}

$0=$ not active $\quad+=$ mild effect $\quad N T=$ not tested; Values were expressed as mean \pm SD; (Diameter on inhibition zone including well diameter of $6 \mathrm{~mm})$, standard for bacteria: amoxicillin, standard for fungi and yeast: canestin .

At the same time, the water extract was effective on B. subtilis $(12.00 \mathrm{~mm})$ while the alcoholic extract recorded $(14.00 \mathrm{~mm})$. Also there was an impact on the strain of L. breveis $(7.00 \mathrm{~mm})$ due to using $80 \%$ alcoholic extract, while there was no effect observed for water extracts of the plant on the same strain, Obvious effect was observed with water extract of $F$. crispa plant on the strain of fungi (A. niger) compared to non-existent effect of the alcoholic extract. Antimicrobial activity was previously investigated. The cited literature reported several biological benefits of wild plants [25-29]

\section{Conclusion}

Dry herb of F. crispa in the flowering stage has various chemical groups. It is rich in volatile oil, carbohydrates, Sterols and/or terpenes and flavonoids. It contains also low amounts of tannins and coumarins. At the same time, the data confirm the absence of alkaloids, saponins and anthraquinones. Twenty-three compounds representing $90.11 \%$ of the Egyptian $F$. crispa essential oil were identified. The main constituents of piperitone $(45.0 \%)$, elemol (8.59\%), $\beta$-eudesmol (8.17\%), $\alpha$-eudesmol (5.35\%), cis nerolidol $(4.5 \%)$ and $\alpha$-terpinene (3.89\%). Other minor compounds were recorded. The antimicrobial activity was tested using gram negative bacteria, gram positive bacteria, yeast and fungi. Water extract of plants under investigation was effective on $E$. coli (12.00) and the inhibition zone was increased up to (15.00) for $80 \%$ alcoholic extract. At the same time, the water extract was effective on B. subtilis (12.00) while the alcoholic extract recorded $(14.00 \mathrm{~mm})$. Also there was an effect on the strain of $L$. breveis $(7.00 \mathrm{~mm})$ due to using $80 \%$ alcoholic extract, while there was no effect of water extracts of the plant on the same strain, Obvious effect was observed with water extract on the strain of fungi (A. niger) compared to non-existent effect of the alcoholic extract . In all cases, in traditional medicine, whole plants or plant mixtures are used instead of isolated compounds. There is evidence that crude plant extracts often have greater in vitro or/and in vivo antimicrobial activity than isolated constituents at an equivalent dose. However wild plants have many medicinal uses makes it very useful in the treatment of human diseases [30]. 


\section{References}

1. L. Boulos, Flora of Egypt .Al-Hadara publishing. Cairo, Egypt. ISBN ( 977-5429-25-0) 3 (2002)

2. A. Al-Rawi, Flora of Kuwait. 2: 1-455. Alden Press Ltd., U.K. (1987).

3. M. Stavri, KT. Mathew, A. Gordon, D. Steven, R. Shnyder, A. Falconer, S. Gibbons, Oliv. Phytochem., 69 (2008) 1915

4. SA. Ross, KA El Sayed, MA. El Sohly, MT. Hamann, OB. Abdel-Halim, AF. Ahmed, MM Ahmed Planta Med., 63 (1997) 479

5. JS. Mossa, MS. Hifnawy, AL Yma, AL Mia, AG. Mekkawi Pharm. Biol., 25(1987) 113

6. HH. EL-Kamali, AH. Ahmed., AS. Mohammed, AM. Yahia., EL Tih, AA. Ali, Fitoterapia. LXIX, (1998) 77

7. MB. Tadhani, VH. Petal, Rs. Subhash. J. Food Compost. Anal., 20 (2007): 323.

8. Y. Li, C. Guo; J Yang, J Wei, J Xu, S Cheng, Food Chem., 96 (2006) 254

9. FZ. Sabri, M.Belarbi, S. Sabri, MS. Alsayadi, J. Nat. Prod. Plant Resour., 2 (. 2012)512.

10. H. H. El-Kamali, and S. A.Mahjoub, Ethnobotanical Leaflets 13: 722-33. 2009

11. F.E. Hanbali, M.Akssira, A. Ezoubeiri, F., Mellouki, A.Benherraf, A.M. Blazquez, H. Boira, J. Ethnopharmacol., 99 (2005) 399-401.

12. M. Znini, G. Cristofari, L. Majidi, J. Paolini, J. Desjobert, J. Costa, LWT-Food Science and Technology, 54 (2013). 564-569

13. N. Ali, F.S. Sharopov, M. Alhaj, G.M. Hill, A. Porzel, N. Arnold, W.N. Setzer, J. Schmidt, L. Wessjohann, Nat Prod Commun7(2012) 257-260.

14. A. Javadinamin, J.Asgarpanah, J. Essential Oil Bearing Plants, 17(2014) 875-879.

15. L. Boulos, Flora of Egypt: A Checklist. Al-Hadara Publishing, Cairo. ISBN-10: 9775429080 (1995)

16. L. Boulos, Flora of Egypt VII Al Hadara Publishing Cairo, Egypt ISBN-13: 9789775429223 (2000)

17. J. F. Clevenger, J Am Pharm Assoc 17(1928) 346.

18. R. P. Adams, Allured, Carol Stream, Illinois, and U.S.A. ISBN:0-931710-42-1 (1995).

19. E. Kováts, Gas-chromatographische charakterisierung organist verbindungen. Teil 1 (1958) DOI: 10.1002/hlca.19580410703

20. E. M. Williamson, D.T. Okpako, F.J. Evans, John Wiley \& Sons, Chichester, ISBN 0471942162 (1998) 15.

21. J. B. Harborne, Phytochemical Methods by Chapman and Hall Ltd. London ISBN: 978-94-010-89562 (1973).

22. CT. Collins, PM. Lyne, Microbiological Methods (5th Edn), Butterworth and Co Pub Ltd, London and Toronto, ISBN 0340808969 (1985) 167

23. R. Mehdi, V.Jafar, N. Meissam, K. Mozhgan, J. Med. Plants Res. 5 (2011). 2035-2040.

24. S. Galambosi, Z.; B. Galambosi; Y. Holm. Finland.J. Essent. Oil Res. 4 (1992) 375.

25. J. B. Harborne, Phytochemical Methods by Chapman and Hall Ltd. London (1973).

26. F. R. Anwar, U. Pak, J. Bot. 39 (2007)1443

27. S.S. Rani, S.P. Rao, M. Krishna, JPRHC 1(2009) 97.

28. H. Adbel baky, G. El baroty, Inter. J. Econ. and Bus. Res. 2(2013):99

29. H E. Yasmin, AM. Mona, AJRC 3(2015)58

30. R. Philippe, W. Colin, L W. Merlin, G. Ben, Malar J. 10 (2011)1.

(2018) ; http://www.jmaterenvironsci.com 